\title{
ANALISIS KESIAPAN SEKOLAH TERHADAP PERUBAHAN KURIKULUM Studi Kasus SMK Perindustrian Yogyakarta dan SMA Negeri 5 Yogyakarta
}

\author{
RIZKA PUSPITASARI, FAIZATIN NUR RAHMAH, AHMAD ADI NUGROHO, FAIZAH NUR \\ KHAMIDAH, MOH. SLAMET SUTRIMO \\ UIN Sunan Kalijaga Yogyakarta \\ Email: rizkarivetra@yahoo.com
}

\begin{abstract}
:
Curriculum is instrument of education on school to supporting goal of national education. The development of era demand the change of curriculum fore the sake of country development. Every country hope can compete with another country in the world. "The progress of country proportionate straint with the progress of education". Because of that, the figure of school as education instantion is very important to release the goal of national education. The school must be ready to confront the change of curriculum. The difference beetwen every curriculum make a trouble in some aspect. Example: evaluation in curriculum 2013 more complex than curriculum KTSP. This matter needs a carefulness of teacher and increasing time of lesson. Because of that, every school must be fill the human resource and infrastructure to support education system.
\end{abstract}

Keywords: curriculum, curriculum management, education system, school, teacher, student

\section{PENDAHULUAN}

endidikan merupakan usaha sadar dan terencana untuk mewujudkan suasana belajar dan proses pembelajaran agar siswa secara aktiv mengembangkan potensi dirinya untuk memiliki kekuatan spiritual keagamaan, pengendalian diri, kepribadian, kecerdasan, akhlak mulia, serta keterampilan yang diperlukan dirinya, masyarakat, bangsa, dan negara. Sebuah kemajuan negara dapat ditinjau dari kemajuan pendidikannya, karena baiknya sumber daya manusia berbanding lurus dengan baiknya sistem pendidikan. Oleh karena itu, manajemen pendidikan sangat diperlukan untuk mencapai sistem yang bermutu.

Arief $\mathrm{K}$ mengatakan bahwa manajemen Pendidikan menerapkan prinsipprinsip manajemen dalam mengelola praksis pendidikan agar berjalan efektif dan efisien, manajemen pendidikan mempunyai prinsip-prinsip yang bertujuan untuk memperoleh output yang bermutu. Untuk mencapai suatu pendidikan yang baik dan berkualitas, maka perlu adanya manajemen baik terutama dalam manajemen kurikulum. Selain itu, pelayanan yang memadai serta sarana dan prasarana yang baik juga akan menunjang kualitas sistem pendidikan. Manajemen kurikulum adalah segenap proses usaha bersama untuk memperlancar pencapaian tujuan pengajaran dengan titik berat pada usaha meningkatkan kualitas interaksi belajar mangajar 
Kurikulum adalah seperangkat rencana dan pengaturan mengenai isi bahan pelajaran serta cara yang digunakan sebagai pedoman penyelenggaraan kegiatan belajar mengajar. Kurikulum merupakan syarat mutlak bagi pendidikan di sekolah , yang berarti bahwa kurikulum merupakan bagian yang tak terpisahkan dari pendidikan dan pengajaran. Sebuah kurikulum memuat nilai-nilai yang menjadi kompetensi yang diharapkan mampu tercapai. Antar satu kurikulum dengan kurikulum yang lain terkadang mempunyai perbedaan dalam kompetensi yang harus dicapai. Dalam proses pendidikan kurikulum mempunyai kedudukan yang penting sebab kurikulum mengarahkan segala bentuk aktivitas pendidikan demi tercapainya tujuan-tujuan pendidikan. Selain itu kurikulum memuat suatu rencana pendidikan, pedoman dan pegangan tentang jenis, lingkup, dan urutan isi serta proses pendidikan.

Kurikulum pendidikan di Indonesia telah banyak mengalami perubahan yang signifikan. Suatu kurikulum disebut mengalami perubahan bila terdapat adanya perbedaan dalam satu atau lebih komponen kurikulum antara 2 periode tertentu, yang disebabkan oleh adanya usaha yang disengaja. Pengubahan tersebut bisa memuat semua yang terlibat didalamnya yaitu guru, murid, kepala sekolah, pemilik sekolah, juga orang tua dan masyarakat.

Ada setidaknya 4 komponen utama yang dimiliki kurikulium,

1. Tujuan-tujuan pendidikan yang ingin dicapai.

2. Pengetahuan dan informasi dari mana-mana.

3. Metode dan cara mengajar untuk mewujudkan kehendak dan tujuan

4. Evaluasi terhadap proses pembelajaran.

Selain itu ada beberapa faktor yang mempengaruhi perubahan Kurikulum:

1. Kemajuan ilmu pengetahuan dan teknologi yang pesat

2. Pertumbuhan yang pesat dari penduduk suatu negara sehingga banyak orang yang membutuhkan pendidikan

3. Tantangan masa depan dan persaingan internasional

4. Demi terwujudnya tujuan pendidikan

Dari beberapa faktor di atas, perubahan kurikulum terjadi demi memperbaiki sistem yang dianggap kurang maksimal sebelumnya. Dengan kurikulum yang baru diharapkan mampu menjawab tantangan zaman dan dapat bersaing dikancah internasional. Teori manajemen yang bagus belum tentu dapat diaplikasikan dengan baik pula, hal ini dikarenakan adanya beberapa kendala yang dihadapi dalam proses tersebut baik yang bersifat fisik maupun non fisik. Oleh karena itu diperlukan sikap profesional untuk menghasilkan manajemen yang professional. Sedangkan untuk mencapai suatu pendidikan yang baik dan berkualitas maka perlu adanya sebuah manajemen yang baik terutama dalam bidang kurikulum yang akan diajarkan kepada anak didik baik mengenai tujuan, isi atau bahan ajar, pelaksanaan serta evaluasi dari kurikulum. 


\section{METODE PENELITIAN}

Metode penelitian yang dilakukan yaitu dengan metode wawancara dan pemberian angket, subjek dalam penelitian ini berfokus pada wakil kepala sekolah bagian kurikulum, guru dan siswa SMK Perindustrian Yogyakarta dan SMA Negeri 5 Yogyakarta kepada Wakil Kepala Kurikulum dan pembagian angket kepada beberapa siswa. Penulis menggunakan dua metode tersebut dengan tujuan agar penelitian yang dilakukan lebih maksimal, artinya pengumpulan data bukan hanya dari guru selaku pendidik melainkan juga dari siswa .

\section{HASIL PENELITIAN DAN PEMBAHASAN}

\section{Analisis Perubahan Kurikulum}

Sebelum diterapkannya kurikulum 2013 yang berbasis karakter , sistem pendidikan di Indonesia menggunakan kurikulum tingkat satuan pendidikan (KTSP) 2006. KTSP adalah sebuah kurikulum operasional pendidikan yang disusun oleh, dan dilaksanakan di masing-masing satuan pendidikan di Indonesia. KTSP harus mengacu pada Standar Isi (SI) dan Standar Kompetensi Lulusan (SKL) untuk pendidikan dasar dan menengah sebagaimana yang diterbitkan melalui Peraturan Menteri Pendidikan Nasional masing-masing Nomor 22 Tahun 2006, dan Nomor 23 Tahun 2006, serta panduan pengembangan KTSP yang dikeluarkan oleh Badan Standar Nasional Pendidikan (BSNP).Namun pada pada tahun 2013 kurikulum ini diganti dengan kurikulum yang berbasis karakter yaitu kurikulum 2013.

Kurikulum 2013 yang berbasis kompetensi dan karakter melibatkan siswa secara aktif, karena siswa adalah pusat dari kegiatan belajar mengajar serta pusat pembentukan kompetensi dan kararakter. Siswa menjadi subjek dengan ikut mengembangkan tema dan materi. Oleh karena itu berbagai standar dalam komponen pendidikan tentunya akan mengalami perubahan termasuk standar isi yang didalamnya berisi kerangka dasar dan struktur kurikulum, beban belajar, dan kalender pendidikan/akademik (Reza, 2016:6).

Antara KTSP 2006 dan Kurikulum 2013, terdapat persamaan dalam hal standar nasional pendidikan, dua-duanya juga diatur oleh Badan Standar Nasional Pendidikan (BSNP). Delapan standar tadi yaitu: Standar Isi, Standar Proses, Standar Kelulusan, Standar Pendidikan dan Tenaga Kependidikan, Standar Sarana dan Prasarana, Standar Pembiayaan, Standar Pengelolaan, dan Standar Penilaian Kependidikan.

Perubahan kurikulum dari KTSP 2006 ke Kurikulum 2013 berbasis karakter ini menimbulkan banyak pro dan kontra dikalangan akademisi. Pro dan kontra tadi tentu tak lepas dari perbedaan yang ada antara KTSP 2016 dengan K-13. Antara lain:

- Pada K-13 jumlah jam pelajaran perminggu lebih banyak dibandingkan dengan KTSP 
- Pada K-13 proses pembelajaran dilakukan dengan pendekatan ilmiah (Saintific Approach) yaitu standar proses dalam pembelajaran terdiri dari mengamati, menanya, mengolah, menyajikan, menyimpulkan, dan mencipta. Sedangkan pada KTSP 2006 standar proses dalam pembelajaran terdiri dari Eksplorasi, Elaborasi, dan konfirmasi

- Pada K-13 proses penilaian nya lebih kompleks dibandingkan dengan KTSP

- Pada K-13 guru dituntut dapat mengoperasikan komputer untuk menyusun RPP dan bahan ajar lainnya.

Dari beberapa perbedaan di atas, kurikulum baru yang diterapkan terlihat memberatkan guru dan siswa. Penambahan jam belajar dan administrasi yang kompleks tentunya membuat guru dan siswa harus berpikir ekstra. Apalagi pada kurikulum yang baru, siswa dituntut aktif, kreatif, dan inovatif dalam belajar. Pada kurikulum k-13, pengajaran diubah dari yang semula gurulah yang menjadi pusat menjadi siswa yang menjadi pusat kegiatan belajar mengajar. Siswa dituntut untuk mencari sumber lain dari materi yang disampaikan guru. Selain itu, penguatan kepribadian dan character building menjadi salah satu poin penting pada setiap pengajaran. Beberapa guru menyayangkan perubahan kurikulum yang berlangsung cepat. Padahal banyak guru yang belum selesai mendalami KTSP tapi malah terjadi perubahan kembali.

Adanya beberapa pro dan kontra serta perubahan yang signifikan membuat penulis berinisiatif untuk mengetahui kesiapan sekolah dalam menerima perubahan kurikulum. Penulis memutuskan untuk observasi terhadap dua sekolah yaitu SMK Perindutrian Yogyakarta dan SMA Negeri 5 Yogyakarta.

\section{Hasil Observasi terhadap kesiapan sekolah dalam menghadapi perubahan kurikulum}

Kami melakukan observasi terhadap dua sekolah yaitu SMK Perindustrian Yogyakarta dan SMA N 5 Yogyakarta untuk mengetahui kesiapan masing-masing sekolah terhadap adanya perubahan kurikulum. Dari observasi tersebut, kami memperoleh informasi mengenai kesiapan masing-masing sekolah yang mana keduanya memiliki persamaan dan perbedaan dalam menghadapi perubahan kurikulum.

Kesiapan SMK Perindustrian Yogyakarta dan SMA Negeri 5 Yogyakarta dalam menghadapi perubahan kurikulum dari KTSP menuju Kurikulum 2013 sebenarnya tidak jauh berbeda. SMK Perindustrian mulai menerapkan Kurikulum 2013 pada tahun 2017 sedangkan SMA Negeri 5 Yogyakarta penerapan kurikulum 2013 sudah berjalan tiga tahun, tepatnya pada tahun 2016. Kedua sekolah tersebut pada dasarnya selalu siap dalam setiap perubahan kurikulum yang terjadi. Hanya saja dalam beberapa proses masih sedikit mengalami kesulitan. SMK Perindustrian Yogyakarta mengalami kesulitan ketika akan menerapkan kurikulum yang baru dikarenakan kondisi siswa yang kurang bisa diatur. Selain itu dalam tahap 
perencanaan perubahan kurikulum, untuk menyusun buku 1, buku 2, dan buku 3 sesuai ketentuan yang berlaku, memerlukan waktu yang cukup lama.

SMA Negeri 5 Yogyakarta cenderung lebih siap dalam menghadapi perubahan kurikulum karena dari segi kondisi siswa, mereka lebih mudah dalam menerima setiap perubahan tersebut. Perubahan kurikulum pada kedua sekolah terlihat memberatkan bagi sebagian guru karena adanya proses administrasi kompleks yang mengharuskan guru mengevaluasi dan menilai setiap butir kompetensi dasar. Hal tersebut tentu membutuhkan perhatian kepada siswa agar penilaian yang diberikan sesuai dengan kemampuan siswa. Kesulitan-kesulitan dalam proses administrasi yang kompleks lebih memberatkan, khususnya bagi beberapa guru yang masa kerjanya hampir habis atau guru senior yang sukar dalam mengoperasikan komputer. Padahal pada kurikulum 2013 semua guru dituntut dapat mengoperasikan komputer sebagai alat untuk membantu proses administrasi. Kemudian adanya penambahan jam pelajaran juga memberatkan bagi pihak guru maupun siswa karena mereka dituntut untuk berpikir lebih.

Kemudian, selain observasi kami juga melakukan penyebaran angket yang berisi tentang seberapa dalam siswa mengetahui tentang kurikulum 2013 dan bagaimana tanggapan siswa sendiri dalam menghadapi perubahan kurikulum tersebut. Mengenai masalah pengetahuan tentang kurikulum 2013, siswa-siswa di SMK Perindustrian Yogyakarta dan SMA Negri 5 Yogyakarta dalam angket dapat disimpulkan bahwa mereka sudah dapat memahami kurikulum 2013 adalah kurikulum yang berbasis karakter, dimana mereka sadar betul bahwa di dalam proses pembelajaran lebih menitiberatkan kepada pemahaman, skill dan karakter. Sedangkan untuk penilaiannya adalah dari aspek sikap, pengetahuan dan keterampilan. Kemudian untuk model pembelajaran di dalam kurikulum 2013, mereka dituntut untuk lebih aktif dalam proses pembelajaran (dari yang awalnya siswa diberitahu menjadi siswa mencari tahu). Selain itu, siswa menganggap bahwa dalam kurikulum 2013 guru memiliki peran yang sangat penting, diantarnya adalah dalam proses pembelajaran guru diharapkan mampu mengetahui potensi dari setiap siswa, sehingga guru dapat membantu mengembangkan potensi tersebut secara maksimal sehingga menjadi sebuah kompetisi.

Walaupun kurikulum 2013 dalam pembelajarannya berpusat kepada siswa, namun mereka beranggapan bahwa penjelasan dari guru merupakan hal yang sangat dibutuhkan karena sebagian besar mata pelajaran SMK Perindustrian Yogyakarta berupa praktek sehingga dapat meminimalisir terjadinya kesalahan konsep. Sedangkan di SMA Negri 5 Yogyakarta juga masih membutuhkan penjelasan dari guru karena ada beberapa materi yang memang harus benar-benar dijelaskan oleh guru agar tidak terjadi kesalahpahaman konsep dalam materi tetapi guru sudah tidak lagi menggunakan metode ceramah.

\section{Pembahasan}


Dalam dunia pendidikan, kebijakannya adalah dengan kebijakan desentralisasi dimana pemerintah hanya akan menetapkan kerangka struktur dasar kurikulum di mana dalam pengembangannya diserahkan kepada masing-masing satuan pendidikan. Untuk itu, setiap satuan pendidikan dituntut agar memiliki kemandirian dalam pengembangan kurikulum. Beberapa kegiatan yang berkenaan dengan fungsi-fungsi manajemen kurikulum perlu dirumuskan melalui langkah-langkah pelaksanaan dan implementasi kurikulum oleh setiap satuan pendidikan. Langkahlangkahnya yaitu perencanaan, pengorganisasian, implementasi, dan evaluasi.

Rangkaian kegiatan pertama dalam proses manajemen adalah tahap perencanaan. Perencanaan kurikulum dimaksudkan memudahkan agar sistem pendidikan yang ada dapat membawa ke arah tercapainya tujuan-tujuan pendidikan. Selain itu perencanaan kurikulum berkaitan penyusunan bahan ajar sehingga siswa mendapatkan pengalaman belajar sesuai yang diharapkan. Semua bahan ajar beserta kegiatannya perlu direncanakan dan disusun dengan baik agar terbentuk kegiatan belajar mengajar yang sistematis.

Tahap perencanaan yang dilakukan oleh dua sekolah yang telah kami observasi dilalui dengan beberapa kendala. Seperti yang sudah tertulis dalam hasil observasi, bahwasannya SMK Perindustrian Yogyakarta mengalami kesulitan dalam perencanaan dikarenakan melihat kondisi siswa yang sepertinya belum mampu untuk melaksanakan kurikulum baru. Selain itu dalam proses penyusunan prota, prosem, silabus, rpp, dan lain sebagainya yang tertuang dalam buku satu, buku dua, dan buku tiga terbilang cukup lama. Sedangkan SMA Negeri 5 Yogyakarta tidak mengalami kesulitan pada tahap perencanaan ini.

Tahapan kedua dalam manajemen kurikulum, yaitu pengorganisasian kurikulum. Pengorganisasian merupakan langkah pertama ke arah pelaksanaan dari perencanaan yang telah tersusun sebelumnya. Pelaksanaan fungsi pengorganisasian dapat menghasilkan suatu organisasi yang bergerak bersama menjadi satu kesatuan dalam rangka upaya pencapaian tujuan. Kesuksesan manajemen dalam pengorganisasian ini dapat dinilai dari kemampuan menciptakan organisasi yang berkualitas. Pengorganisasian kurikulum terkait dengan penyusunan bahan pelajaran yang ada dalam kurikulum dan harus mempertimbangkan ruang lingkup dan urutan bahan pelajaran, kontinuitas kurikulum, keseimbangan bahan pelajaran, dan alokasi waktu.

Dalam penyusunan jadwal pelajaran, SMK Perindustrian Yogyakarta tidak ada kesulitan dikarenakan guru-guru kelas XI dan XII yang menggunakan kurikulum KTSP dan guru-guru kelas X dengan kurikulum 2013 adalah guru-guru yang berbeda. Sedangkan SMA Negeri 5 Yogyakarta yang pada dasarnya sangat siap dalam menerima perubahan kurikulum, hanya mengalami kesulitan dalam penyusunan jadwal pelajaran. Penempatan mata pelajaran yang memerlukan pemikiran lebih, diupayakan untuk dapat diletakkan pada jam-jam pelajaran awal agar lebih efektif dan efisien. Namun, cukup sulit untuk membuat perlakuan yang sama di setiap mata 
pelajaran dan di setiap kelas karena banyak guru yang meminta agar jamnya didahulukan melihat kondisi siswa.

Pada tahap implementasi merupakan penerapan atau pelaksanaan program dari hal-hal yang telah dikembangkan tahap-tahap sebelumnya, diujicobakan dengan pelaksanaan dan pengelolaan, serta dilakukan penyesuaian terhadap situasi kondisi lapangan dan karakteristik peserta didik, baik perkembangan secara intelektual, emosional, serta fisiknya. SMK Perindustrian Yogyakarta tidak mengalami kesulitan dalam proses pelaksanaan kurikulum baru pada kelas $X$ dikarenakan siswa mereka sudah mengalami kurikulum 2013 sejak masih Sekolah Menengah Pertama, berbeda jika penerapannya pada siswa kelas XI dan Kelas XII yang mana lebih sulit diatur. Sedangkan SMA Negeri 5 Yogyakarta pun juga tidak mengalami kesulitan karena memang sekolah tersebut sudah menjadi sekolah favorit yang mana siswanya lebih mudah dikondisikan. Apalagi dalam setiap perubahan kurikulum, siswa hanya mengikuti serangkaian aturan kegiatan yang diberikan oleh guru sehingga siswa selalu siap menerima perubahan yang ada. Keberhasilan pelaksanaan kurikulum sangat dipengaruhi oleh penerapan guru di kelas. Seindah apapun desain kurikulum, pada akhirnya tetap terletak di tangan guru sehingga kurikulum-kurikulum apapun yang diberlakukan pemerintah, tidak akan berpengaruh, kecuali guru dapat memainkan perannya dengan baik.

Selanjutnya tahapan terakhir, yaitu evaluasi. Tahap evaluasi melalui proses yang sistematis dari pengumpulan, analisis dan interpretasi data untuk melihat kemanjuan siswa dalam mencapai tujuan. Selain itu, evaluasi digunakan untuk memeriksa kinerja kurikulum secara keseluruhan mana yang efektivitas, efisiensi, relevansi, dan kelayakan (feasibility) program. Oleh sebab itu, evaluasi kurikulum memegang peranan pentin dalam menentukan kebijakan dan pengambilan keputusan. Hasil-hasil evaluasinya juga dapat digunakan oleh seluruh elemen pendidikan, dalam memahami perkembangan siswa, memilih bahan pelajaran, memilih metode dan alat-alat bantu pelajaran, cara penilaian serta fasilitas pendidikan lainnya.

SMK Perindustrian Yogyakarta dan SMA Negeri 5 Yogyakarta memiliki sedikit kesulitan dalam proses evaluasi khususnya evaluasi pada kemampuan hasil belajar siswa. Seperti yang telah di jelaskan pada poin hasil observasi, sistem penilaian kurikulum 2013 lebih rumit dikarenakan guru harus menilai setiap butir kompetensi dasar dan kemudian dilakukan analisis. Agar proses penilaian lebih mudah, guru dituntut untuk menguasai teknologi khususnya komputer. Sayangnya, banyak guru yang sudah tua kesulitan dalam mengikuti perkembangan teknologi sehingga berdampak pada proses penilaian yang berlangsung cukup lama. Selain kesulitan dalam mengoperasikan komputer, guru-guru tersebut juga motivasi mengajarnya sudah berkurang karena masa baktinya sudah hampir habis.

Pada dasarnya setiap perubahan kurikulum memiliki tujuan dan harapan yang baik, demi memajukan pendidikan. Hanya saja dalam realisasinya masih banyak 
mengalami kekurangan ketika diterapkan di sekolah-sekolah tertentu. Hal tersebut dikarenakan perencanaan kurikulum dilakukan oleh pihak pusat kemudian diturunkan kepada setiap satuan pendidikan hingga sampai ke guru-guru. Namun dalam proses perencanaan oleh pusat, guru-guru tidak dilibatkan langsung. Guruguru hanya bertindak sebagai pelaku pasif yang hanya menerima dan melaksanakan kurikulum di lapangan. Wakil kepala kurikulum SMA Negeri 5 Yogyakarta mengungkapkan sedikit mengenai perencanaan tersebut. Beliau kurang setuju dengan perencanaan melalui pendekatan yang bersifat administratif tersebut. Pihak pusat sebagai pemberi ide, gagasan, dan inisiatif membuat perencanaan, tetapi mereka belum mengetahui kondisi di lapangan yang sesungguhnya. Mereka hanya berbekalan teori dan berusaha menciptakan kurikulum yang baik tanpa melihat kesanggupan setiap satuan pendidikan.

Pada saat proses ujicoba kurikulum baru, sekolah-sekolah yang ditunjuk untuk mencoba menerapkannya adalah sekolah-sekolah yang berkualitas sehingga jelas bahwa ujicoba tersebut dapat berhasil dan berjalan dengan baik. Pihak perencana pusat berpandangan bahwa pengambilan ujicoba beberapa sekolah yang berhasil, sudah dapat dijadikan pedoman dalam pengambilan keputusan untuk menerapkan kurikulum baru. Padahal sebenarnya, banyak sekolah lain yang sedang berkembang maupun terbelakang justru mengalami banyak kesulitan dalam penerapannya. Oleh karena itu, guru sebagai pemegang peran yang sangat penting dalam merealisasikan kurikulum perlu dilibatkan pada saat proses perencanaan pusat. Dengan adanya keterlibatan guru, setidaknya perencanaan yang dilakukan dapat sesuai dengan kondisi-kondisi di lapangan.

\section{KESIMPULAN}

Berdasarkan penelitian dan pembahasan, dapat disimpulkan bahwa dari observasi yang dilakukan terhadap dua sekolah menengah yaitu SMK Perindustrian Yogakarta dan SMA Negeri 5 Yogyakarta menunjukan hal positif, hanya saja SMA Negeri 5 Yogyakarta cenderung lebih siap dibandingkan SMK Perindustrian Yogyakarta. Hal tersebut dikarenakan sumber daya manusia yang ada di SMA Negeri 5 Yogyakarta lebih memadai serta sarana dan prasarananya pun lebih mendukung. Namun kedua sekolah tersebut sama-sama mempunyai kesulitan pada proses evaluasi. Seperti yang dijelaskan diatas, dibandingkan dengan KTSP 2006, Kurikulum 2013 menuntut evaluasi yang mendetail pada setiap butir kompetensi dasar (KD). Hal tersebut tentunya lebih kompleks dan membutuhkan ketelitian dan kesabaran, serta berpikir ekstra keras. Peran guru terhadap perubahan kurikulum ini dirasa cukup vital karena guru harus menyesuaikan perubahan kurikulum kepada siswa-siswanya. Setiap kurikulum mempunyai tujuan masing-masing, tetapi kurikulum yang diterapkan tidak akan mencapai tujuan tanpa adanya peran guru yang baik. Oleh karena itu, pendidik harus benar-benar mempunyai kompetensi berkualitas yang tercakup dalam 4 hal, yaitu kompetensi pedagogik, kompetensi 
professional, kompetensi sosial, dan kompetensi personal. Jika kompetensi yang dibutuhkan benar-benar terpenuhi maka akan mendukung tercapainya tujuan pendidikan nasional, mencerdaskan kehidupan bangsa. Cerdas secara intelektual, cerdas secara spiritual, dan cerdas secara emosional.

\section{DAFTAR PUSTAKA}

Arifin, Zainal (2012). Konsep dan Model Pengembangan Kurikulum, Cet II. Bandung: PT. Remaja Rosdakarya.

Khoirudin, Arif (2013). Manajemen Kurikulum Dalam Meningkatkan Mutu Pendidikan. Institut Agama Islam Tribakti (IAIT) Kediri.

Nasbi, Ibrahim (2017). MANAJEMEN KURIKULUM: Sebuah Kajian Teoritis. Jurnal Idaarah, Vol. I.

Reza, Fahmi. Skripsi: “Pengaruh Penerapan Kurikulum 2013 terhadap Hasil Belajar Siswa pada Mata Pelajaran Sosiologi Kelas X Semester Genap Di SMA Negeri 01 Batu" (Malang: UIN Maulana Malik Ibrahim, 2016). 